\title{
Decoupling between Plant Productivity and Growing Season Length under a Warming Climate in Canada's Arctic
}

\author{
Wenjun Chen' ${ }^{1}$, Paul Zorn'2 ${ }^{2}$ Lori White ${ }^{3}$, Ian Olthof ${ }^{1}$, Yu Zhang ${ }^{1}$, Robert Fraser ${ }^{1}$, \\ Sylvain Leblanc ${ }^{1}$ \\ ${ }^{1}$ Canada Centre for Remote Sensing, Natural Resources Canada, Ottawa, Canada \\ ${ }^{2}$ Parks Canada Agency, Gatineau, Canada \\ ${ }^{3}$ Wildlife Landscape Science Directorate, Environment Canada, Ottawa, Canada \\ Email:wenjun.chen@canada.ca,paul.zorn@pa.gc.ca, lori.white@ec.gc.ca, ian.olthof@canada.ca, \\ yu.zhang@canada.ca, Robert.fraser@canada.ca,sylvain.leblanc@canada.ca
}

Received 9 May 2016; accepted 13 August 2016; published 16 August 2016

Copyright (C) 2016 by authors and Scientific Research Publishing Inc.

This work is licensed under the Creative Commons Attribution International License (CC BY).

http://creativecommons.org/licenses/by/4.0/

c) (i) Open Access

\section{Abstract}

Given the short duration of growing season in the Arctic, a strong correlation between plant productivity and growing season length (GSL) is conventionally assumed. Will this assumption hold true under a warming climate? In this study, we addressed the question by investigating the relationship between net primary productivity of leaves (NPP ${ }_{\text {leaf }}$ ) and GSL for various tundra ecosystems. We quantified NPP leaf $_{\text {la }}$ and GSL using long-term satellite data and field measurements. Our results indicated that the relationship was not significant (i.e., decoupled) for $44 \%$ to $64 \%$ of tundra classes in the southern Canadian Arctic, but significant for all classes in the northern Canadian Arctic. To better understand the causes of the decoupling, we further decomposed the relationship into two components: the correspondence of interannual variations and the agreement of longterm trends. We found that the longer the mean GSL for a tundra class, the poorer the correspondence between their interannual variations. Soil moisture limitation further decoupled the relationship by deteriorating the agreement of long-term trends. Consequently, the decoupling between NPP leaf and GSL would be more likely to occur under a warming climate if the tundra class had a mean GSL > 116 (or 123) days with a dry (or moist) soil moisture regime.

\section{Keywords}

Net Primary Productivity, Growing Season Length, Arctic Tundra, Decoupling, Remote Sensing, Soil Moisture Regime 


\section{Introduction}

Net primary productivity (NPP, g biomass $\mathrm{m}^{-2} \mathrm{y}^{-1}$ ) is fundamental to an arctic tundra ecosystem's functions and services, such as food for wildlife and feedback to climate [1]-[3]. Arctic temperatures have increased at almost twice the global average rate in the past 100 years and are predicted to continue at a higher rate than the rest of the planet [4] [5]. Along with rising temperature, an increase in growing season length (GSL, d) during the last few decades has also been reported [5]. Measurements of and GSL showed coincident declines from low latitudes to high northern latitudes [6]. Tundra warming experiments have also shown increases in both plant productivity and GSL [7]. Consequently, many climate-vegetation models have assumed a uniform response of plant growth to temperature and GSL, and reduction of arctic tundra [8] [9].

A circumarctic study of relationships between shrub growth and climate variables (including GSL), however, raised doubt about this assumption [10]. Shrub growth at many Arctic sites, especially in the Canadian Arctic, was found to have no significant relationship with climatic variables at the $90 \%$ confidence level. In other words, shrub growth and GLS at these sites were decoupled.

Building on the findings of the paper [10], we aim to investigate if such decoupling has also occurred for other tundra classes. Also, we will investigate the reasons of the decoupling. Among many possible reasons, we noticed that the distance between a shrub growth study site and the nearest climate station can be quite large in some cases, especially in the Canadian Arctic where climate stations were very sparse [10]. The difference between the climate conditions at a shrub site and those at its nearest climate station could thus weaken and even decouple the relationship. To circumvent this difficulty, in this study we use leaf NPP (NPP leaf) and GSL derived from the same source of long-term remote sensing time series over various tundra ecosystems in Canada's Arctic.

\section{Material}

\subsection{Study Areas}

According to the Canadian ecozone classification [11], two study areas (i.e., Ivvavik National Park (NP), Bathurst caribou summer range and calving ground) are located in the Southern Arctic Ecozone (Figure 1). The other two (i.e., Sirmilik and Torngat Mountains NP) in the Northern Arctic and Arctic Cordillera Ecozones.

The 1760 m high British Mountains dominate Ivvavik NP in northern Yukon. The park escaped glaciations

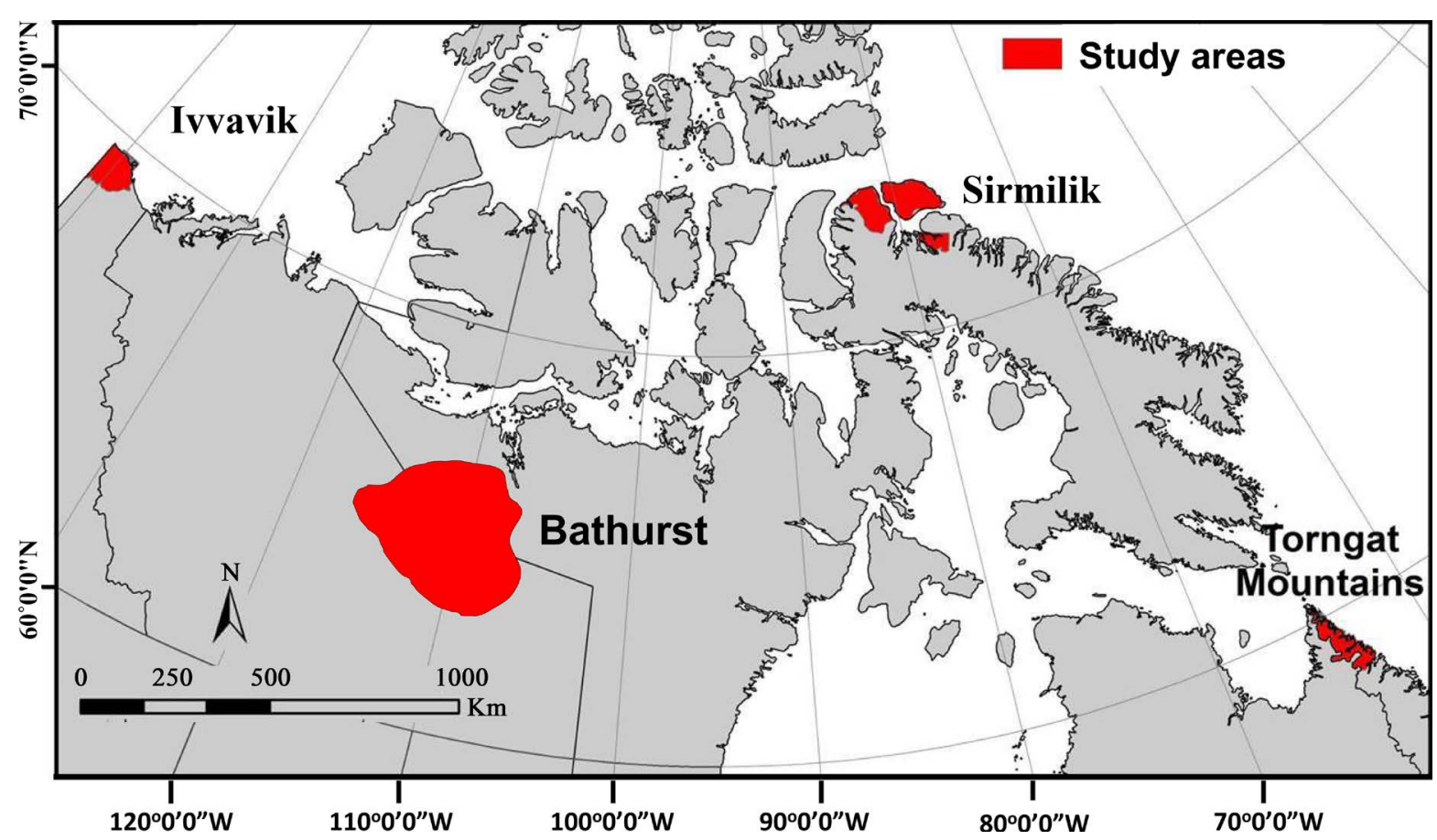

Figure 1. Location of four study areas in the Canadian Arctic, including Ivvavik, Sirmilik, Torngat Mountains National Parks, as well as the Bathurst caribou summer range and calving ground. 
during the last Ice Age, except along its cottongrass tussock dominated northern coast. The Bathurst caribou habitat is a relatively flat rolling tundra shield, located in NWT and Nunavut. The Sirmilik NP is composed of the mountain and upland surrounding Oliver Sound, the rugged plateau of eastern Borden Peninsula, and Bylot Island. The Bylot Island features glaciers and a major seabird colony on its southwestern coast. Although its latitude is further south comparing to the Southern Arctic study areas, the Torngat Mountains NP also belongs to Northern Arctic and Arctic Cordillera Ecozones. The mean annual temperature and total precipitation at the Qikiqtarjuaq climate station, the nearest station from the Torngat Mountains NP in the same ecozone, indicate that it is colder and drier than the two Southern Arctic study areas (Table 1). The Torngat Mountains NP composes the George Plateau and the Torngat Mountains, which is the highest peak (1652 m) in east coast North America and dotted with remnant glaciers.

\subsection{Data Sources}

To produce NPP leaf and GLS for each tundra class in the four study areas from 1985 to 2013, we used long-term satellite data the Advanced Very-High-Resolution Radiometer (AVHRR). The AVHRR data are pre-processed 10-day composites at 1-km spatial resolution, including the red and near-infrared surface reflectance (i.e., $\rho_{r}$ and $\rho_{\text {nir }}$ ) and cloud probability. Pre-press procedures include geo-referencing, the Bidirectional Reflectance Distribution Function (BRDF) correction, atmospheric correction, cloud indexing, and inter-sensor normalization [12].

Field measurements for calibrating and validating the remote sensing products of $\mathrm{NPP}_{\text {leaf }}$ and GLS include leaf biomass and percentage vegetation cover. Leaf biomass and percentage vegetation cover were collected during July and August at 11 sites in the Ivvavik NP in 2008, at 16 sites in Torngat Mountains NP in 2008, at 11 sites in Sirmilik NP in 2010, and at 34 sites in the Bathurst caribou habitat during 2005, 2013 and 2014.

To directly match an AVHRR pixel, a suitable site would have to be homogeneous and at least $3 \mathrm{~km}$ by $3 \mathrm{~km}$ because of the possibilities of different orientations and partial overlapping between them. Our experience suggested that it could be difficult to find enough such sites in the Arctic, where topographical variations often resulted in a heterogeneous landscape. Therefore, our criteria for site selection were at least $90 \mathrm{~m}$ by $90 \mathrm{~m}$ or the size of three Landsat pixels. The 30-m resolution Landsat images were then used to bridge the scale difference between leaf biomass measurement sites and AVHRR pixels. We developed a Landsat mosaic for each of the four study areas cloud-free circa 2000 scenes, following paper [13]. Given the mismatch in the dates often found between field measurements and their corresponding Landsat mosaic, a correction is needed to convert the vegetation indices calculated using the Landsat mosaic to that on the dates of field measurements. To carry out the correction, we used the daily 250-m data of the Moderate Resolution Imaging Spectroradiometer (MODIS), which acquires data daily approximately $15 \mathrm{~min}$ after Landsat data in the same polar orbit.

Tundra classes at 1-km resolution for each of the four study area were aggregated from 30-m Landsat-based land cover maps [14]-[16]. Soil moisture regime index was determined using field survey records and DEM data [17]. The DEM tiles at 1:50,000 were downloaded from Geobase (www.geobase.ca). The climate data (temperature and precipitation) are available from Canadian Daily Climate Data (CDCD) (www.climate.weatheroffice.gc.ca).

\section{Methods}

\subsection{In-Situ Measurements of Vegetation Variables}

Growing season lengths in the Canadian Arctic are very short, ranging from a few weeks to a few months. Dur-

Table 1. Study areas, their attributes, and the nearest climate station with the good data record in the same ecozone.

\begin{tabular}{|c|c|c|c|c|c|}
\hline Study area & Area $\left(\mathrm{km}^{2}\right)$ & $\begin{array}{l}\text { Latitude/longitude } \\
\text { center }\end{array}$ & Ecozone & $\begin{array}{l}\text { Nearest climate } \\
\text { station }\end{array}$ & $\begin{array}{l}\text { Annual mean Temperature } \\
\text { (total precipitation) }\end{array}$ \\
\hline Ivvavik NP & 9750 & $\begin{array}{l}69^{\circ} 36^{\prime} 00^{\prime \prime} \mathrm{N} \\
140^{\circ} 10^{\prime} 00^{\prime \prime} \mathrm{W}\end{array}$ & $\begin{array}{l}\text { Southern Arctic \& } \\
\text { taiga cordillera }\end{array}$ & Inuvik & $-8.2^{\circ} \mathrm{C}(240.6 \mathrm{~mm})$ \\
\hline Bathurst caribou habitat & 112,000 & $65^{\circ} 8^{\prime} 5^{\prime \prime} \mathrm{N} 111^{\circ} 7^{\prime} \mathrm{W}$ & $\begin{array}{l}\text { Southern Arctic \& } \\
\text { tundra shield }\end{array}$ & Lupin & $-10.9^{\circ} \mathrm{C}(298.5 \mathrm{~mm})$ \\
\hline Sirmilik NP & 22,200 & $72^{\circ} 50^{\prime} 4 " \mathrm{~N} 80^{\circ} 34^{\prime} 55^{\prime \prime} \mathrm{W}$ & $\begin{array}{l}\text { Northern Arctic \& } \\
\text { Arctic cordillera }\end{array}$ & Pond Inlet & $-14.6^{\circ} \mathrm{C}(189.0 \mathrm{~mm})$ \\
\hline Torngat Mountains NP & 9700 & $59^{\circ} 22^{\prime} 12^{\prime \prime} \mathrm{N} 63^{\circ} 38^{\prime} 48^{\prime \prime} \mathrm{W}$ & Arctic cordillera & Qikiqtarjuaq & $-11.0^{\circ} \mathrm{C}(203 \mathrm{~mm})$ \\
\hline
\end{tabular}


ing the short growing season, leaf biomass values are relatively stable from middle July to middle August. This period was thus selected as the most suitable period for conducting field measurement of leaf biomass, for the purpose of calibrating and validating remote sensing products.

We select a field measurement site to be relatively homogenous and of a minimum size of $90-\mathrm{m} \times 90-\mathrm{m}$, to match with a Landsat pixel [18]. At each site, we typically sampled five to twenty $1-\mathrm{m} \times 1-\mathrm{m}$ plots [18]. The number of plots per site was determined by balancing the need to go to more sites in a study area with the need to have more plots in a site. Statistics from our results indicate that to ensure a site is well represented (i.e., the sampling error $<20 \%$ ), we need to have five plots per site for sites with vascular plant percentage cover $>20 \%$, and 20 plots per site for sites with lower vascular plant percentage covers. Field measurements in the remote Canadian Arctic are expensive and time-consuming because many sites are accessible only by helicopter. To maximize the value of helicopter time, we usually included measurements other than leaf biomass and percentage covers (e.g., permafrost depth, soil properties and moisture regime, roots biomass, and foliage photosynthesis capacity) in a field campaign. Consequently, a team of 4 to 5 researchers usually was only able to measure leaf biomass and percentage covers for one or two sites per day. A summer's field campaign thus usually allowed us to collect leaf biomass and percentage covers 10 - 25 sites in a study area. To avoid sites overly concentrated at the dominant land cover classes, we intentionally included sites with at the high and low ends of biomass range.

At each plot, percentage covers of vascular plant species were visually estimated in the field and corrected by digital photo classification in the laboratory [19]. All plants were then harvested, identified to species, sorted into dead versus live as well as leaves versus stems, and weighed in the field. Samples of these leaves and stems were also taken to the laboratory and oven-dried and weighed to obtain the oven-dry leaf biomass. We calculated the values of leaf biomass and percentage cover at each site as the average of all plots at the site.

\subsection{Method for Quantifying NPP leaf}

NPP includes the production of leaves, stems, roots, flowers, and fruits of vascular plants, as well as the production of non-vascular plants (e.g. lichen, mosses). For ecosystems in the Canadian Arctic, it was suggested that belowground NPP may strongly related to its aboveground counterpart [20], although paper [21] found there were not enough root production measurement to be conclusive. Therefore, $\mathrm{NPP}_{\text {leaf }}$ can be used as a good surrogate for NPP in Canada's Arctic.

By definition, $\mathrm{NPP}_{\text {leaf }}$ is the net increase of leaf biomass from the start of growing season to its peak value. As such, $\mathrm{NPP}_{\text {leaf }}$ is given by (the seasonal peak SRVI - the SRVI at the SOS) $\times$ the slope of the relationship between leaf biomass and SRVI. Here SRVI is the AVHRR-based simple ratio vegetation index $\left(=\rho_{\text {nirr }} / \rho_{r}\right)$. In this study, we used SRVI, instead of the commonly used normalized differential vegetation index (NDVI), because the relationships between NDVI and leaf biomass over arctic tundra ecosystems are usually nonlinear and have a lower explanation power than that between SRVI and leaf biomass [22].

Despite the selection of the best day within a 10-d period through compositing techniques and other preprocessing efforts, the remnant cloud contamination and aerosol variations could still result in an up to $40 \%$ error in the seasonal peak value of SRVI [13]. To reduce the large error in the seasonal peak value of SRVI, we constructed seasonal profiles of SRVI for each land cover class, instead of each AVHRR pixel [23]. We divided the pixels of a tundra class in a given 10-d composite period into four categories: clear sky, lightly, moderately, and heavily cloud contaminated, with the cloudiness index $<20 \%, 20$ to $<40 \%, 40$ to $<60 \%$, and $\geq 60 \%$, respectively. SRVI over cloud contaminated pixels in a tundra class then was corrected against that of clear-sky pixels in the class during the same 10-d composite. Table 2 lists the multipliers for correlating (the value of mean SRVI-1) of cloud contaminated pixels in a tundra class to that of clear pixels in the class for the four study areas in the Canadian Arctic. With these correction coefficients, we were able to reduce the error in SRVI of a land class to $<10 \%$.

Next, we determined the slope of the relationship between leaf biomass and SRVI while describing the quantification of the SRVI at the SOS in section 3.3. Due to the spatial mismatch between the size of a field measurement site and that of an AVHRR pixel, we cannot directly develop the relationship between leaf biomass and AVHRR-derived SRVI. Instead, we used Landsat mosaic to bridge their scale difference. Landsat images were pre-processed, which included 1) co-registration of images; 2) atmospheric correction to obtain surface reflectance in red and near infrared, using a procedure based on 6S (Second Simulation of Satellite Signal in the Solar Spectrum) described by reference [24]. The atmospheric parameters (i.e., atmospheric water vapor mean, 
Table 2. Multipliers for correlating (the value of mean SRVI -1) of cloud contaminated pixels in a tundra class to that of clear pixels in the class for the four study areas in the Canadian Arctic.

\begin{tabular}{|c|c|c|c|c|}
\hline \multicolumn{2}{|r|}{ Land cover class } & \multicolumn{3}{|c|}{ Correlation coefficients for pixels contaminated by clouds } \\
\hline Label & Name & Lightly & Moderately & Heavily \\
\hline $\mathrm{I} 1$ & Alpine slope & 1.177 & 1.971 & 3.112 \\
\hline $\mathrm{I} 2$ & Willow-horsetail wet slope & 1.184 & 1.893 & 2.787 \\
\hline I3 & Rock lichen & 1.238 & 2.189 & 2.982 \\
\hline I4 & Willow-birch moist slope & 1.212 & 2.048 & 3.486 \\
\hline $\mathrm{I} 10$ & Willow floodplain & 1.214 & 1.582 & 1.762 \\
\hline $\mathrm{I} 18$ & Cottongrass tussock & 1.141 & 2.246 & 2.822 \\
\hline $\mathrm{I} 20$ & Willow-sedge pediment drainage channel & 1.112 & 1.639 & 2.571 \\
\hline $\mathrm{I} 22$ & Sand/silt & 1.440 & 2.378 & 216.6 \\
\hline $\mathrm{I} 23$ & Hedysar-avens inactive alluvial Terrace & 1.184 & 1.173 & 1.197 \\
\hline $\mathrm{I} 25$ & Willow-coltsfoot drainage channel & 1.142 & 2.604 & 1.915 \\
\hline I26 & Sedge tussock & 1.024 & 1.956 & 2.404 \\
\hline B16 & Shrub moist & 1.343 & 3.121 & 3.625 \\
\hline B19 & Shrub mesic & 1.430 & 2.679 & 4.731 \\
\hline $\mathrm{B} 23$ & Herb & 1.278 & 2.790 & 3.777 \\
\hline B26 & Lichen-shrubs-herb, bare soil/rock outcrop & 1.305 & 2.321 & 1.972 \\
\hline B28 & Low vegetation cover (bare soil, rock outcrop) & 1.167 & 1.960 & 3.692 \\
\hline B35 & Lichen barren & 1.271 & 2.148 & 2.741 \\
\hline B36 & Lichen-shrub-herb-bare & 1.158 & 2.293 & 2.746 \\
\hline В38 & Rock outcrop, low vegetation cover & 1.209 & 2.314 & 3.353 \\
\hline B41 & Low vegetation cover & 1.206 & 2.108 & 3.726 \\
\hline $\mathrm{S} 1$ & Tussock graminoid tundra & 1.249 & 1.316 & 2.049 \\
\hline S2 & Wet sedge & 1.294 & 2.072 & 3.156 \\
\hline S3 & Moist-dry non-tussock graminoids/dwarf shrub & 1.754 & 2.443 & 2.384 \\
\hline S7 & Prostrate dwarf shrub & 1.286 & 1.691 & 1.658 \\
\hline S8 & Sparsely vegetated bedrock & 1.215 & 1.622 & 1.788 \\
\hline S9 & Sparsely vegetated till-colluvium & 1.021 & 1.247 & 1.400 \\
\hline S10 & Bare soil with cryptogam crust-frost boils & 1.288 & 1.795 & 2.154 \\
\hline S12 & Barren & 1.067 & 1.505 & 1.756 \\
\hline $\mathrm{T} 16$ & Deciduous shrub (>75\% cover) & 1.187 & 2.566 & 3.452 \\
\hline $\mathrm{T} 23$ & Herb-shrub & 1.464 & 2.062 & 3.092 \\
\hline $\mathrm{T} 24$ & Shrub-herb-lichen-bare & 1.013 & 1.506 & 2.917 \\
\hline $\mathrm{T} 26$ & Lichen-shrubs-herb, bare soil/ rock outcrop & 1.240 & 1.345 & 2.844 \\
\hline $\mathrm{T} 28$ & Low vegetation cover (bare soil, rock outcrop) & 1.258 & 1.768 & 1.911 \\
\hline T35 & Lichen barren & 1.296 & 2.098 & 2.631 \\
\hline Т36 & Lichen-shrub-herb-bare & 1.228 & 1.786 & 2.019 \\
\hline T38 & Rock outcrop low vegetation cover & 1.140 & 1.473 & 1.614 \\
\hline
\end{tabular}

total ozone mean, and optical depth and ocean Mean) were developed from the MODIS instrument, which acquires data daily approximately 15 min after Landsat data in the same polar orbit; and 3) cloud and shadow masking. For creating the mosaic, we kept a baseline image intact and normalized other images to it through equations developed over the overlapping areas.

Because of the 16-day repeat cycle and frequent cloud cover, acquiring Landsat images exactly corresponding 
to the field measurement date is often impossible. As a result, substitute Landsat images acquired on another date or year are often used. Given that there are substantial seasonal and inter-annual variations in foliage biomass, such substitution can significantly increase the error in the relationship between leaf biomass and Landsat-derived signals due to the mismatch between the date of Landsat image acquisition and that of field measurement. To minimize this error, we made a correction using MODIS daily 500-m surface reflectance data. We developed relationships for MODIS band 1 (or 2) between the date of Landsat acquisition and that of field measurement and then applied this relationship to the Landsat red (or near-infrared) surface reflectance to correct the Landsat reflectance to the day of field measurement, using an approach similar to paper [25]. Table 3 lists the statistics for the relationships between leaf biomass and Landsat-derived SRVI for the four study areas in the Canadian Arctic. Applying these relationships to the Landsat mosaic, we developed leaf biomass maps for each study area, as exemplified in Figure 2 for the Ivvavik NP.

Table 3. Statistics for the relationships between leaf biomass and SRVI derived from Landsat imagery or AVHRR data for the four study areas in the Canadian Arctic. Here $n$ is the sample size.

\begin{tabular}{|c|c|c|c|c|c|c|}
\hline Study area & & Intercept & Slope & $R^{2}$ & $p$-value & $n$ \\
\hline \multirow{2}{*}{ Ivvavik } & Landsat & -62.82 & 46.009 & 0.98 & $<0.01$ & 11 \\
\hline & AVHRR & -26.94 & 20.946 & 0.77 & $<0.01$ & 331 \\
\hline \multirow{2}{*}{ Bathurst } & Landsat & -34.23 & 26.887 & 0.89 & $<0.01$ & 25 \\
\hline & AVHRR & -36.40 & 25.512 & 0.68 & $<0.01$ & 833 \\
\hline \multirow{2}{*}{ Sirmilik } & Landsat & -28.96 & 23.238 & 0.92 & $<0.01$ & 11 \\
\hline & AVHRR & -22.98 & 18.447 & 0.91 & $<0.01$ & 409 \\
\hline \multirow{2}{*}{ Torngat Mountains } & Landsat & -37.76 & 18.717 & 0.78 & $<0.01$ & 16 \\
\hline & AVHRR & -25.65 & 19.618 & 0.81 & $<0.01$ & 225 \\
\hline
\end{tabular}

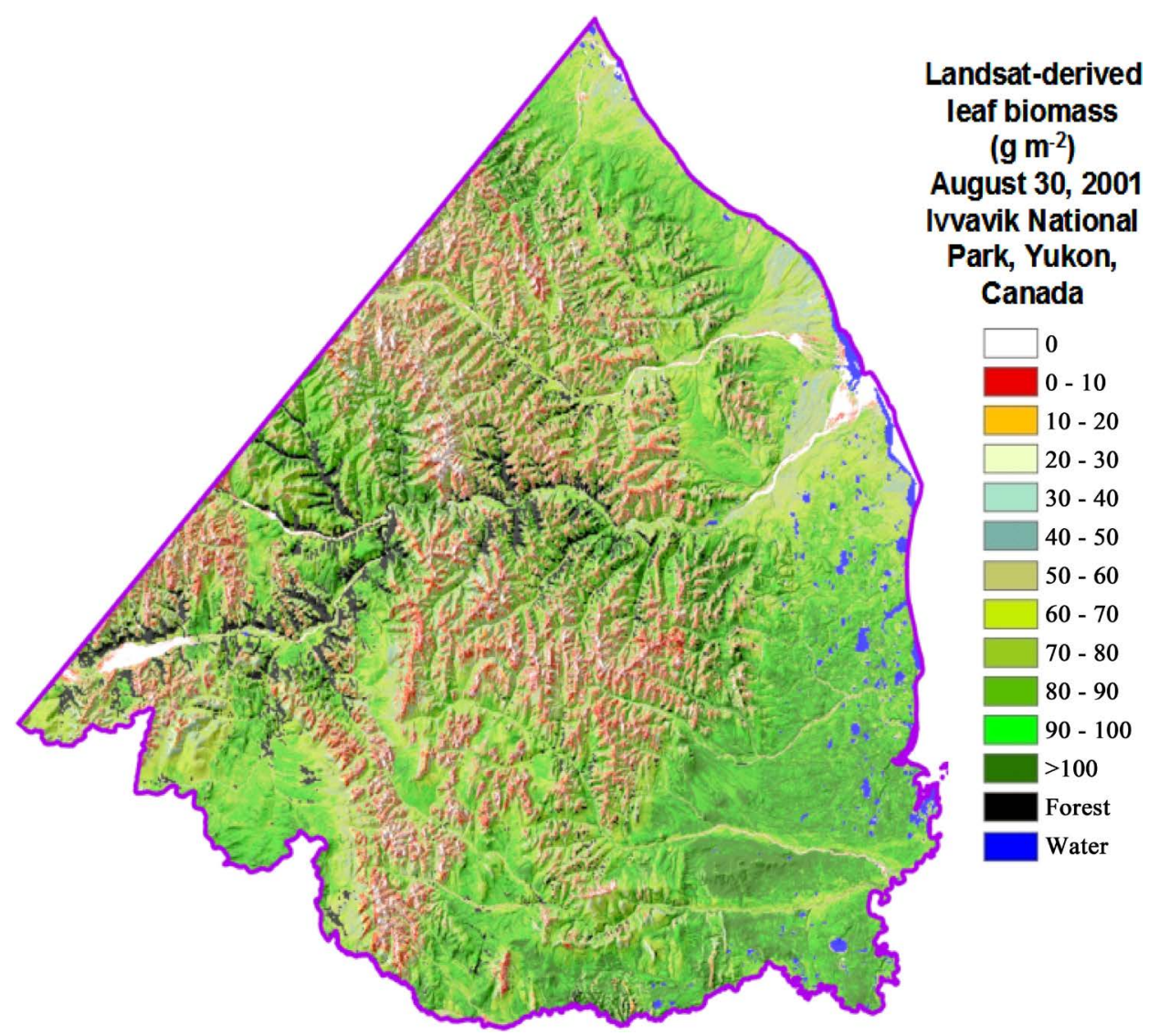

Figure 2. Landsat-derived leaf biomass map over the Ivvavik National Park. We used DEM data for a three-dimensional effect. 
Using these leaf biomass maps, we can calculate 1-km resolution leaf biomass distribution and relate them to AVHRR-derived SRVI. To reduce the random error in AVHRR SRVI for a clear sky pixel, we averaged AVHRR-derived SRVI and leaf biomass to a window of 25 pixels, as a compromise between final accuracy in the averaged AVHRR SRVI and a large enough sample number for the regression [13]. The slopes of the relationships between leaf biomass and AVHRR-derived SRVI for the four study areas in the Canadian Arctic was also listed in Table 3.

\subsection{Method for Determining Plant Seasonality}

We used the Biophysically-based and Objective Satellite Seasonality Observation Method (BLOSSOM) for determining GSL [26]. Biophysically, the date of SOS or EOS can be defined as the day of the year on which the leaf biomass of deciduous shrubs and herbs equals zero [26]. Due to the existence of evergreen shrubs in most tundra sites, AVHRR-derived SRVI threshold at the SOS (or EOS) was determined by considering contributions from both evergreen shrubs and other components. The other land surface components might include dead leaves and stems of deciduous shrubs and herbs, lichens, mosses, bare soil, rocks, and shadows. The contribution of evergreen shrubs to the SOS threshold was determined by the percentage cover of evergreen shrubs in a tundra class and their surface reflectance while the contribution from other components was given by (-intercept/ slope) for each study area listed in Table 3. Table 4 lists the percentage cover of evergreen shrubs in a tundra class and the SOS (or EOS) AVHRR-derived SRVI threshold for each class in the four study areas.

As shown in Figure 3, the SOS was determined as the day of the year on which class average AVHRR SRVI first became larger than the threshold in the spring. Similarly, the EOS was determined as the day of the year on which class average AVHRR SRVI first became less than the threshold in the fall. Since snow could sometimes revisit a vegetated area around SOS or EOS in the Arctic, and result in multiple crossings of AVHRR SRVI through the threshold line, only the first crossing with certainty in the spring would be determined as SOS. All other days before this date should have no class mean AVHRR SRVI-its one standard estimation error were larger the threshold. Similarly, only the first crossing with certainty in the fall would be determined as EOS. The GSL was then determined as the difference between the date of EOS and the date of SOS plus one day.

\subsection{Calculation of Soil Moisture Regime Index and Coupling Strength of a Relationship}

Paper [17] determined soil moisture regime index (SMRI) for the Firth River Valley, a part of the Ivvavik NP, by information of soil texture and topography. They set the value of SMRI for a given soil moisture regime to be: 1 stands for the driest xeric regime, 2 for subxeric, 3 for submesic, 4 for mesic, 5 for subhygric, 6 for hygric, 7 for subhydric, and 8 for the wettest hydric regime. Following the same method, we calculated the SMRI for each class in the four study areas, by combining information from soil texture survey during our field campaigns and

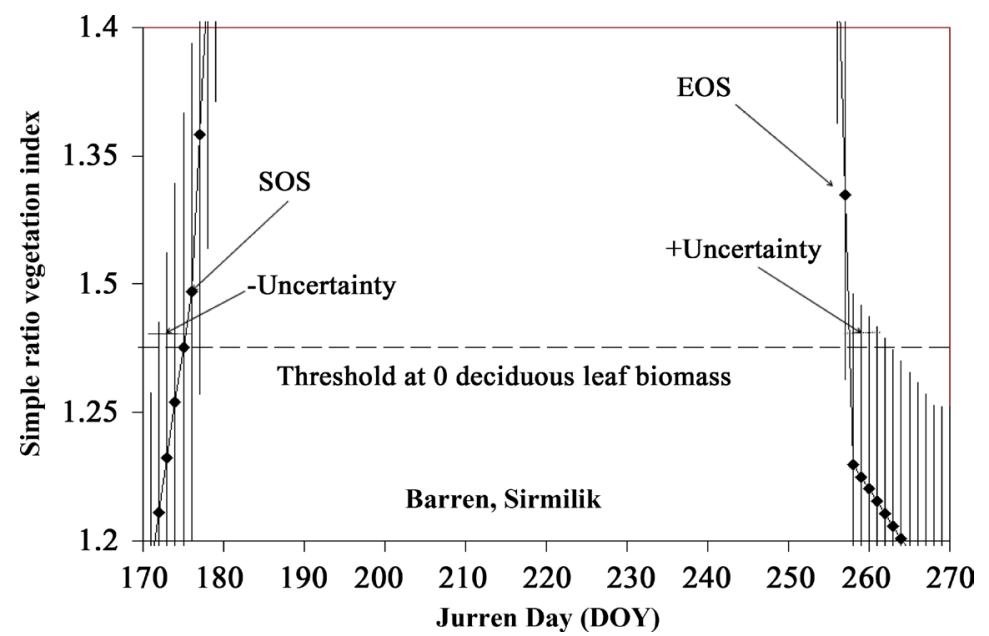

Figure 3. An example showing the determination of SOS, EOS, and GSL for the barren class in Sirmilik NP in 2007. The vertical bars show one standard error in AVHRR SRVI of the class while the horizontal bars show the corresponding under (or over-) estimation of SOS and EOS. 
Table 4. Percentage cover of evergreen shrubs and SOS (or EOS) threshold for each class in the four study areas. Also listed are the mean values of $\mathrm{NPP}_{\text {leaf }}$ and GSL, long-term trends of $\mathrm{NPP}_{\text {leaf }}$ and GSL during 1985-2013, the correlation coefficient $R_{c s}$ between $\mathrm{NPP}_{\text {leaf }}$ and GSL, $R_{d t}$ between de-trended $\mathrm{NPP}_{\text {leaf }}$ and de-trended GSL, soil moisture regime index, and the percentage of a tundra class out of the total tundra-covered area in a study area. Long-term trends statistically significant at the 99\%, 95\%, and 90\% levels are labeled as ${ }^{* * *},{ }^{* *}$, and ${ }^{*}$, respectively.

\begin{tabular}{|c|c|c|c|c|c|c|c|c|c|c|}
\hline $\begin{array}{l}\text { Class } \\
\text { label }\end{array}$ & $\begin{array}{c}\text { Evergreen } \\
\text { shrubs cover } \\
\text { (\%) }\end{array}$ & $\begin{array}{l}\text { SOS (or EOS) } \\
\text { threshold }\end{array}$ & $\begin{array}{c}\text { Mean NPP } \mathrm{NP}_{\text {leaf }} \\
\left(\mathrm{g} \cdot \mathrm{m}^{-2} \cdot \mathrm{y}^{-1}\right)\end{array}$ & $\begin{array}{l}\mathrm{NPP}_{\text {leaf }} \text { trend } \\
\left(\mathrm{g} \cdot \mathrm{m}^{-2} \cdot \mathrm{y}^{-2}\right)\end{array}$ & $\begin{array}{l}\text { Mean GSL } \\
\text { (d) }\end{array}$ & $\begin{array}{l}\text { GLS trend } \\
\left(\mathrm{d} \cdot \mathrm{y}^{-1}\right)\end{array}$ & $R_{c s}$ & $R_{d t}$ & SMRI & $\%$ land area \\
\hline I1 & 43.0 & 1.386 & 55.0 & 1.11 & 127 & 0.91 & 0.30 & 0.08 & 2 & 12.6 \\
\hline I2 & 11.3 & 1.307 & 57.9 & 0.97 & 131 & 0.87 & 0.28 & 0.08 & 5 & 12.2 \\
\hline I3 & 10.6 & 1.306 & 35.6 & 0.42 & 120 & 0.82 & $0.37^{*}$ & 0.24 & 1 & 29.3 \\
\hline I4 & 17.0 & 1.319 & 68.5 & 1.18 & 137 & 0.83 & 0.24 & 0.05 & 4.5 & 2.7 \\
\hline I10 & 13.0 & 1.311 & 45.0 & 0.81 & 119 & 0.54 & $0.48^{* * *}$ & 0.27 & 5 & 0.4 \\
\hline I18 & 13.7 & 1.312 & 72.0 & 2.05 & 131 & 0.63 & 0.18 & -0.06 & 6 & 37.6 \\
\hline I20 & 0.0 & 1.286 & 77.0 & 2.02 & 130 & 0.66 & 0.20 & -0.05 & 6.5 & 0.5 \\
\hline I22 & 0.0 & 1.286 & 38.9 & 0.48 & 121 & 0.79 & $0.41^{* *}$ & 0.30 & 1 & 0.3 \\
\hline I23 & 27.3 & 1.343 & 33.0 & 0.49 & 110 & 0.51 & $0.32^{*}$ & 0.18 & 1.5 & 1.1 \\
\hline I25 & 0.0 & 1.286 & 73.4 & 1.94 & 134 & 0.65 & 0.23 & -0.01 & 5.5 & 1.0 \\
\hline I26 & 8.3 & 1.302 & 60.7 & 1.17 & 124 & 0.58 & 0.26 & 0.04 & 6 & 2.3 \\
\hline B16 & 0 & 1.427 & 79.3 & 1.26 & 132 & 0.84 & 0.28 & 0.07 & 7 & 0.1 \\
\hline B19 & 5.1 & 1.438 & 77.7 & 1.14 & 145 & 0.87 & 0.12 & -0.09 & 6 & 0.1 \\
\hline B23 & 18.2 & 1.468 & 65.3 & 1.07 & 128 & 0.78 & $0.37^{*}$ & 0.18 & 5 & 65.3 \\
\hline B26 & 15.5 & 1.461 & 54.4 & 0.75 & 118 & 0.82 & $0.38^{* *}$ & 0.28 & 4 & 0.1 \\
\hline B28 & 35.0 & 1.507 & 23.5 & 0.09 & 112 & 1.01 & $0.48^{* * *}$ & $0.49^{* * *}$ & 1 & 0.5 \\
\hline B35 & 0 & 1.427 & 43.2 & 0.69 & 115 & 0.74 & $0.33^{*}$ & 0.19 & 2 & 9.2 \\
\hline B36 & 0 & 1.427 & 33.1 & 0.48 & 113 & 0.75 & $0.34^{*}$ & 0.24 & 1.5 & 23.9 \\
\hline B38 & 11.3 & 1.453 & 46.1 & 0.18 & 139 & 1.41 & 0.25 & 0.23 & 1 & 0.03 \\
\hline B41 & 15.5 & 1.462 & 80.3 & 1.17 & 139 & 1.20 & 0.21 & -0.12 & 5 & 0.7 \\
\hline S1 & 13.8 & 1.275 & 26.0 & 2.58 & 89 & 0.61 & $0.49^{* * *}$ & $0.43^{* *}$ & 2 & 3.1 \\
\hline S2 & 8.8 & 1.264 & 24.7 & 2.91 & 96 & 0.76 & $0.51^{* * *}$ & $0.42^{* *}$ & 5.5 & 9.4 \\
\hline S3 & 7.3 & 1.261 & 15.5 & 1.94 & 85 & 0.85 & $0.63^{* * *}$ & $0.56^{* * *}$ & 5 & 6.8 \\
\hline S7 & 19.2 & 1.288 & 18.3 & 2.77 & 76 & 0.86 & $0.69^{* * *}$ & $0.62^{* * *}$ & 4 & 8.1 \\
\hline S8 & 3.9 & 1.254 & 7.7 & 1.73 & 63 & 1.10 & $0.79^{* * *}$ & $0.77^{* * *}$ & 3 & 11.9 \\
\hline S9 & 0.0 & 1.246 & 5.9 & 1.54 & 49 & 1.18 & $0.64^{* * *}$ & $0.61^{* * *}$ & 1 & 25.6 \\
\hline S10 & 0.0 & 1.246 & 15.4 & 1.56 & 83 & 1.04 & $0.63^{* * *}$ & $0.58^{* * *}$ & 1.5 & 6.1 \\
\hline S12 & 0.0 & 1.246 & 15.0 & 2.82 & 76 & 1.23 & $0.70^{* * *}$ & $0.67^{* * *}$ & 1.5 & 28.9 \\
\hline T16 & 0.0 & 1.308 & 64.9 & 1.81 & 123 & 1.31 & $0.56^{* * *}$ & $0.35^{*}$ & 6.5 & 0.4 \\
\hline $\mathrm{T} 23$ & 18.3 & 1.349 & 49.0 & 1.21 & 127 & 1.43 & $0.54^{* * *}$ & 0.30 & 6 & 3.4 \\
\hline T24 & 15.2 & 1.342 & 72.8 & 2.74 & 116 & 0.90 & $0.60^{* * *}$ & $0.49^{* * *}$ & 5.5 & 0.2 \\
\hline T26 & 15.2 & 1.342 & 42.3 & 1.30 & 120 & 1.41 & $0.62^{* * *}$ & $0.41^{* *}$ & 4 & 2.5 \\
\hline T28 & 35.0 & 1.388 & 8.0 & 0.37 & 69 & 1.64 & $0.83^{* * * *}$ & $0.80^{* * * *}$ & 1 & 66.4 \\
\hline T35 & 0 & 1.308 & 24.5 & 0.56 & 107 & 1.27 & $0.64^{* * *}$ & $0.49^{* * *}$ & 1.5 & 19.3 \\
\hline T36 & 0 & 1.308 & 24.1 & 0.48 & 107 & 1.25 & $0.67^{* * *}$ & $0.55^{* * *}$ & 2 & 4.4 \\
\hline T38 & 11.3 & 1.333 & 4.9 & 0.29 & 52 & 1.50 & $0.904^{* *}$ & $0.91^{* * *}$ & 1 & 3.5 \\
\hline
\end{tabular}


topographic information from DEM data (Table 4).

We defined the coupling strength between $\mathrm{NPP}_{\text {leaf }}$ and GLS as their correlation coefficient $\left(R_{c s}\right)$. To better understand the causes of the decoupling, we further decomposed the relationship into two components: the correspondence of inter-annual variations and the agreement of long-term trends. The pure inter-annual variation of $\mathrm{NPP}_{\text {leaf }}$ (or GLS) refers to the change from year to year after the long-term trend has been removed. Therefore, we calculated the contribution of the correspondence between interannual variations to the coupling strength between $\mathrm{NPP}_{\text {leaf }}$ and GLS as the correlation coefficient $\left(R_{d t}\right)$ between the de-trended $\mathrm{NPP}_{\text {leaf }}$ and de-trended GLS. The de-trended $\mathrm{NPP}_{\text {leaf }}$ (or GLS) was calculated as $\mathrm{NPP}_{\text {leaf }}$ (or GSL) - its trend value at a given year. Since there is only one value for the long-term trend of $\mathrm{NPP}_{\text {leaf }}$ and another for that of GLS, direct calculation of the contribution of the agreement between long-term trends to the coupling strength between $\mathrm{NPP}_{\text {leaf }}$ and GLS is not possible. Instead, we can estimate the contribution of the agreement between long-term trends as $\left(R_{c s}-R_{\mathrm{dt}}\right)$.

\section{Results and Discussions}

\subsection{States and Trends of NPP leaf and GSL across the Four Study Areas}

The mean $\mathrm{NPP}_{\text {leaf }}$ of a tundra class during 1985-2013 ranged from 23.5 to $80.3 \mathrm{~g} \cdot \mathrm{m}^{-2} \cdot \mathrm{y}^{-1}$ over the two southern study areas, and from 4.9 to $72.6 \mathrm{~g} \cdot \mathrm{m}^{-2} \cdot \mathrm{y}^{-1}$ over the two southern study areas (Table 4). Our results are comparable with results of other studies in the Canadian Arctic, with aboveground NPP (ANPP) ranging from 0.7 to 60 $\mathrm{g} \cdot \mathrm{m}^{-2} \cdot \mathrm{y}^{-1}$ for high Arctic sites and 28 to $125 \mathrm{~g} \cdot \mathrm{m}^{-2} \cdot \mathrm{y}^{-1}$ for low Arctic sites [27]. Note that $\mathrm{NPP}_{\text {leaf }}$ is the largest component of ANPP, we expect NPP leaf being somewhat lower than ANPP.

Within a study area, the values of mean $\mathrm{NPP}_{\text {leaf }}$ of a tundra class during 1985-2013 could differ by several folds. For example in the Ivvavik NP, the willow-sedge pediment drainage channel class (i.e., I20) had a mean $\mathrm{NPP}_{\text {leaf }}$ during 1985-2013 of $70 \mathrm{~g} \cdot \mathrm{m}^{-2} \cdot \mathrm{y}^{-1}$, contrasting to that of the hedysar-avens inactive alluvial terrace class (I23) at $33 \mathrm{~g} \cdot \mathrm{m}^{-2} \cdot \mathrm{y}^{-1}$. The largest difference in $\mathrm{NPP}_{\text {leaf }}$ was found between the shrub-herb-lichen-bare class (T24) and the rock outcrop low vegetation cover class (T38) in the Torngat Mountains NP: $72.8 \mathrm{~g} \cdot \mathrm{m}^{-2} \cdot \mathrm{y}^{-1}$ versus 4.9 $\mathrm{g} \cdot \mathrm{m}^{-2} \cdot \mathrm{y}^{-1}$. In comparison, the difference in GSL among classes within a study area was not as large as that in $\mathrm{NPP}_{\text {leaf }}$. For example, the GSL of the willow-sedge pediment drainage channel class was $130 \mathrm{~d}$, while that of the hedysar-avens inactive alluvial terrace class $110 \mathrm{~d}$ in the Ivvavik NP. The largest difference in GSL was found between the herb-shrub class (T23) and the rock outcrop low vegetation cover class (T38) in the Torngat Mountains NP: $127 \mathrm{~d}$ versus $52 \mathrm{~d}$.

When averaged over all tundra classes in a study area weighted by area percentages, the mean values of $\mathrm{NPP}_{\text {leaf }}$ of the two southern Arctic study areas (i.e., Ivvavik NP and the Bathurst caribou summer range and calving ground) during 1985-2013 were, respectively, $55.5 \mathrm{~g} \cdot \mathrm{m}^{-2} \cdot \mathrm{y}^{-1}$ and $56.5 \mathrm{~g} \cdot \mathrm{m}^{-2} \cdot \mathrm{y}^{-1}$. For the two northern Arctic study areas, the mean values of $\mathrm{NPP}_{\text {leaf }}$ during the same period were much smaller: $13.4 \mathrm{~g} \cdot \mathrm{m}^{-2} \cdot \mathrm{y}^{-1}$ over the Sirmilik NP and $14.4 \mathrm{~g} \cdot \mathrm{m}^{-2} \cdot \mathrm{y}^{-1}$ over the Torngat Mountains NP. Correspondingly, the values of study area averaged GSL during 1985-2013 in the southern Arctic study areas were $127 \mathrm{~d}$ over the Ivvavik NP and $123 \mathrm{~d}$ over the Bathurst caribou habitat. To the contrary, the values of study area averaged GSL in the northern Arctic study areas were $71 \mathrm{~d}$ over the Sirmilik NP and $81 \mathrm{~d}$ over the Torngat NP.

Note that the percentage of a tundra class was calculated against the total tundra-covered area in a study area. Glaciers, water bodies, and wetland classes were excluded in the calculation. In the Sirmilik NP, the glaciers account for about $40 \%$ of total area of park land. If they were included in the study area averaged $\mathrm{NPP}_{\text {leaf }}$ and GSL calculation, their values would be even smaller. We also noticed that these study area averaged values of $\mathrm{NPP}_{\text {leaf }}$ and GSL were mainly controlled by their most dominant classes. For example, in the Torngat Mountains NP, the low vegetation cover (bare soil, rock outcrop) class alone accounted for $66.4 \%$ of total tundra area in the park, followed by the lichen barren at $19.3 \%$. Small classes, such as the deciduous shrub class $(0.4 \%)$ and the shrub-herb-lichen-bare class (0.2\%), did not contribute to the study area averaged $\mathrm{NPP}_{\text {leaf }}$ despite their much higher values of $\mathrm{NPP}_{\text {leaf }}($ Table 4$)$.

As for the long-term trends of $\mathrm{NPP}_{\text {leaf }}$ and GSL, large variations were also observed among tundra classes within a study area. All classes in the four study areas were found to have increasing trends in their $\mathrm{NPP}_{\text {leaf }}$ and GSL, although some of the trends were not statistically significant at the $90 \%$ confidence level. The largest difference in the long-term trends of $\mathrm{NPP}_{\text {leaf }}$ was observed between the rock outcrop low vegetation cover class (T38) and the shrub-herb-lichen-bare (T24): 0.29 versus $2.74 \mathrm{~g} \cdot \mathrm{m}^{-2} \cdot \mathrm{y}^{-1}$ per year. Typically, the difference in the long-term trends of GSL between classes in a study area was smaller than that of $\mathrm{NPP}_{\text {leaf }}$, which was consistent 
with the finding for their mean values. More analyses of these long-term trends are reported in section 4.4.

\subsection{Relationships between NPP leaf and GSL during 1985-2013}

Figure 4 shows examples of covariations between NPP leaf and GSL. The NPP $\mathrm{Peaf}_{\text {lef }}$ the willow-birch moist slope class in the Ivvavik NP increased significantly during 1985-2013, with $R^{2}=0.25, p=0.005$, and sample size $n=$ 29. During the same period, its GSL also increased significantly $\left(R^{2}=0.15, p=0.04\right)$. Yet, despite of their common increasing trends, they were decoupled (i.e., not significant at the $90 \%$ confidence level), with $R^{2}=$ $0.06, p=0.21$, and $n=29$.

Seven out of the 11 tundra classes (i.e., 64\%) in the Ivvavik NP, their NPP ${ }_{\text {leaf }}$ and GSL were decoupled during 1985-2013 (Table 4). Similar to the finding of paper [10], many of shrub classes in the Ivvavik NP (e.g., class I2 the willow-horsetail wet slope, I4 the willow-birch moist slope, I20 the Willow-sedge pediment drainage channel, and I25 the willow-coltsfoot drainage channel) had decoupled relationship between $\mathrm{NPP}_{\text {leaf }}$ and GSL during 1985-2013. Other shrub classes (e.g., class I10 the willow floodplain) had a strongly coupled relationship between $\mathrm{NPP}_{\text {leaf }}$ and GSL during the same period. The results were similar for other land cover classes. For example, classes that had decoupled relationship between NPP ${ }_{\text {leaf }}$ and GSL include I1 the alpine slope, I18 the cottongrass tussock, and I26 the sedge tussock. On the other hand, other classes (e.g., I3 the rock lichen, I22 the sand/silt, and I23 the hedysar-avens inactive alluvial terrace) had a coupled relationship between $\mathrm{NPP}_{\text {leaf }}$ and GSL, although their coupling strengths were not as significant.

For the Bathurst caribou habitat, similar variable results were found. Four out of 9 tundra classes (i.e., 44\%) in the Bathurst caribou habitat, their NPP leaf and GSL were decoupled during 1985-2013 (Table 4). Both shrub classes (i.e., B16 and B19) had a decoupled relationship between $\mathrm{NPP}_{\text {leaf }}$ and GSL. Different from the Ivvavi NP, the herb class in the Bathurst caribou habitat had a coupled relationship between $\mathrm{NPP}_{\text {leaf }}$ and GSL during

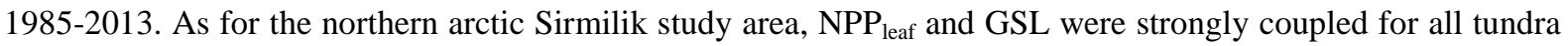
classes (Table 4), including the barren class (Figure 4).

To further investigate the impacts of climate change on the relationship between $\mathrm{NPP}_{\text {leaf }}$ and GSL, we compared their coupling strength between the first 10-year period (i.e., 1985-1994) and the last 10-year period (i.e., 2004-2013). For the two southern Canadian Arctic study areas, we found the majority of classes $(75 \%$ for the Ivvavik NP and $78 \%$ for the Bathurst study area, respectively) had a reduced coupling strength from the first 10-year period to the last 10-year period. To the contrary for the two northern Canadian Arctic study areas, we found only about half of classes (67\% for the Similik NP and 38\% for the Torngat study area, respectively) had a reduced coupling strength between the two periods.

A question then arises as to what controlled the coupling strength of the relationship between $\mathrm{NPP}_{\text {leaf }}$ and GSL? We addressed this question by investigating both components of the relationship: the correspondence of inter-annual variations and the agreement of long-term trends, in the flowing two sections.

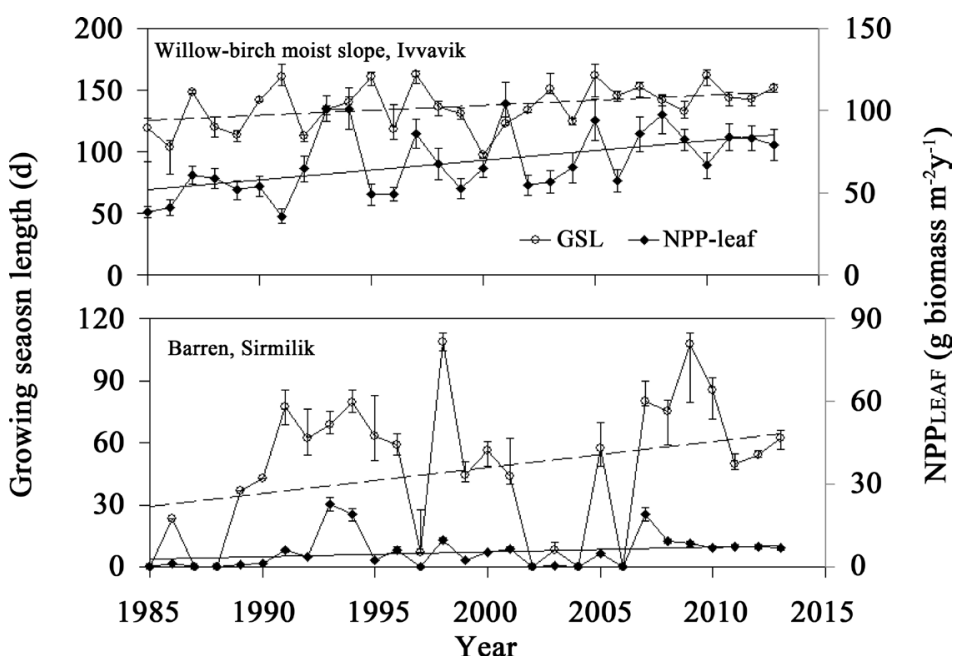

Figure 4. Trends in $\mathrm{NPP}_{\text {leaf }}$ and GSL of the willow birch moist slope class in Ivvavik NP, and the barren class in Sirmilik NP during 1985-2013. Error bars show uncertainties at one standard deviation. 


\subsection{Correspondences between Interannual Variations in NPP leaf and GSL}

We analyzed the correspondence between their inter-annual variations against various mean characteristics of a land cover class within a study area, such as long-term mean leaf biomass and GSL during 1985-2013, mean elevation of all pixels of the class, and SMRI. We found that the mean GSL to be the most significant variable for explaining the change in the correspondence.

As Figure 5 shows, the ratio of sign agreement between de-trended $\mathrm{NPP}_{\text {leaf }}$ (i.e., $\mathrm{NPP}_{\text {leaf }}-$ trend value of $\mathrm{NPP}_{\text {leaf }}$ ) and de-trended GSL (i.e., GSL - trend value of GSL) for the barren class in the Sirmilik NP during $1985-2013$ was $100 \%$ for years with GSL $<30$ d. The ratio of sign agreement was computed as years with agreed signs divided by the total years in a given GSL range. The high ratio values for years with GSL $<30 \mathrm{~d}$ are understandable because it usually takes a couple of weeks to dry out soil, even for sites with very coarse soil texture in the Arctic [20]. Because leaf biomass usually peaks near the middle of a growing season, there would be almost no chance of drought for years with GSL $<30 \mathrm{~d}$. The ratio decreased quickly for years with GSL $>30$ $\mathrm{d}$ to $\sim 50 \%$, the threshold corresponding to complete decoupling. In other words, in years with longer GSL, factors such as soil moisture limitation, herbivore grazing, or insect defoliation had a much bigger chance to become influential, resulting in decoupled $\mathrm{NPP}_{\text {leaf }}$ and GSL. The ratio of sign agreement in years with GSL $>30 \mathrm{~d}$ in Ivvavik NP was slightly higher than that in Sirmilik NP, probably because Ivvavik NP has higher precipitation and thus might take a longer period to develop drought.

The overall lower ratio of sign agreement for the willow-birch moist slope class in the Ivvavik NP might also be explained by the difference in temperature sensitivity for $\mathrm{NPP}_{\text {leaf }}$ and GSL. During 1985-2013, GSL of the class was significantly correlated with the mean temperature in the months of May, June, September, and October (i.e., spring and fall temperature in the southern Canadian Arctic), with $R^{2}=0.31$ and $\mathrm{p}<0.01$. However, they were not correlated with mean summer temperature during July and August, with $R^{2}=0.006$ and $\mathrm{p}>0.1$. On the other hand, $\mathrm{NPP}_{\text {leaf }}$ was related to the July and August mean temperature $\left(R^{2}=0.12\right.$ and $\left.p<0.1\right)$, but not with spring and fall temperature $\left(R^{2}=0.0002\right.$ and $\left.p>0.1\right)$, similar to the finding of by paper [28]. No significant relationship was found between precipitation and $\mathrm{NPP}_{\text {leaf }}$ or GSL for all time periods.

These different sensitivities, in fact, support the argument that other factors such as soil moisture limitation, herbivore grazing, or insect defoliation might constrain plant growth. Otherwise, if all these factors' impacts were negligible, then an earlier and better spring growth should have also resulted in higher $\mathrm{NPP}_{\text {leaf }}$.

For the barren class in the Sirmilik NP, $\mathrm{NPP}_{\text {leaf }}$ was decoupled with the mean July and August temperature $\left(R^{2}\right.$ $=0.093, p=0.107$, and $n=29$ ). The decoupled relationship was a remarkable contrast to the high coupling

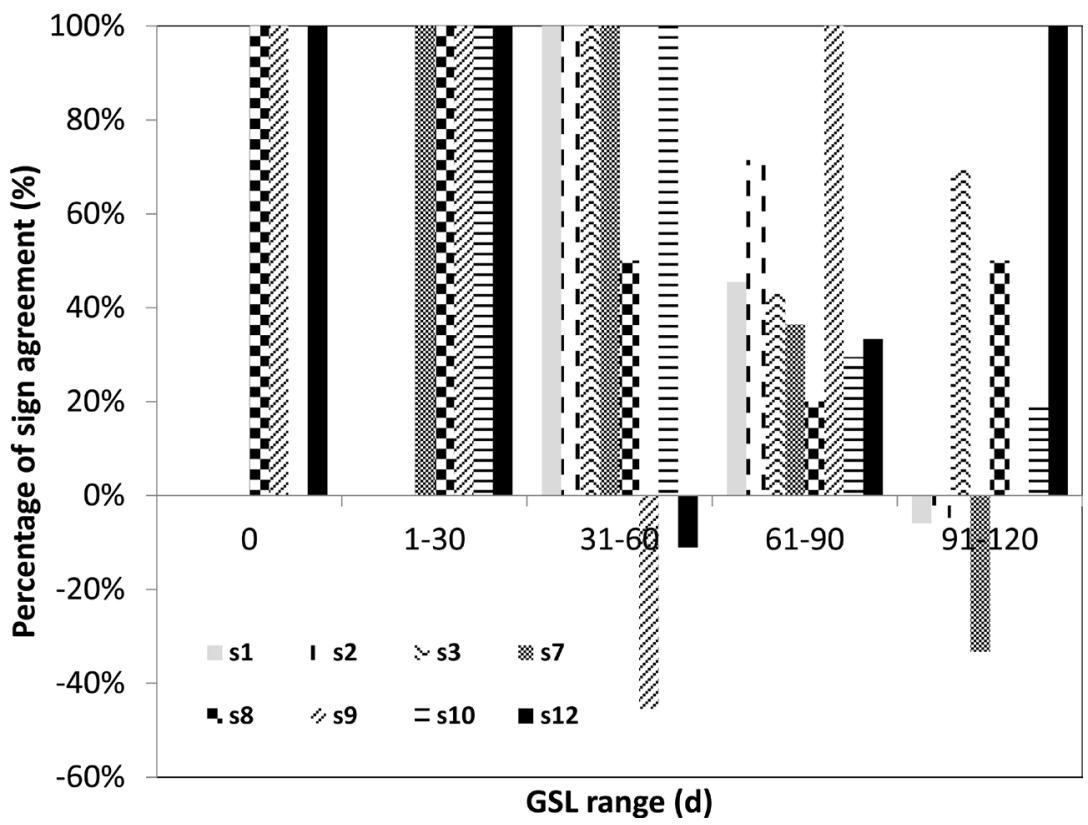

Figure 5. Percentage of sign agreement between de-trended NPP ${ }_{\text {leaf }}$ and de-trended GSL in a GSL range for each class in the Sirmilik NP during 1985-2013. See the class label in Table 2. 
strength between its $\mathrm{NPP}_{\text {leaf }}$ and GSL $\left(R^{2}=0.34\right.$ and $\left.p<0.01\right)$ for the class. We suspected that the tempo-spatial mismatch between climate and NPP data might be responsible for the contradiction.

The percentage of years with GSL $<30 \mathrm{~d}$ increases as the mean GSL of a tundra class decreases. Therefore, we used the mean GSL of the class as a proxy to represent the chance for factors such as soil moisture limitation, herbivore grazing, and insect defoliation to become influential. A significant relationship was found between the coupling strength between de-trended NPP $\mathrm{Neaf}_{\text {lea }}$ and de-trended GSL $\left(R_{d t}\right)$ and the mean GSL of a tundra class $(\overline{G S L}$ ) over the four study areas (Figure 6):

$$
R_{d t}=-0.000041(\overline{G S L})^{2}-0.000415 \overline{G S L}+0.8817 \text {, with } R^{2}=0.71, p<0.01 \text {, and } n=36 .
$$

As shown in Figure 6, the inter-annual correspondence between de-trended NPP ${ }_{\text {leaf }}$ and de-trended GSL became statistically insignificant for some of the classes that had a long-term mean GSL > 100 d during 1985-2013. When the long-term mean GSL was > 120 d, nearly all classes had an insignificant correspondence between de-trended $\mathrm{NPP}_{\text {leaf }}$ and de-trended GSL.

\subsection{Agreements between Long-Term Trends in NPPleaf and GSL}

As for the agreement between long-term trends, we found that the SMRI was the dominant factor. Plotting the SMRI against the contribution of the agreement between long-term trends of $\mathrm{NPP}_{\text {leaf }}$ and GSL to the coupling strength (i.e., $R_{c s}-R_{d t}$ ), we found a significant reduction of this contribution when moving from the wettest tundra class to the driest tundra class for all four study areas (Figure 7, Table 5). For some of the driest tundra ecosystems, such as the rock outcrop low vegetation cover in the Torngat Mountains NP or the low vegetation cover (bare soil, rock outcrop) in the Bathurst caribou summer range and calving ground, this contribution even became negative.

These results clearly demonstrated the limitation of soil moisture on the contribution of NPP $_{\text {leaf }}$ and GSL trends to the coupling strength. One possible explanation is that a dry class with lower SMRI tended to limit the increase in $\mathrm{NPP}_{\text {leaf }}$ (Figure 8). The ratios of $\mathrm{NPP}_{\text {leaf }}$ trend of the wettest class to that of driest class during 1985-2013 were 4.8, 7.0, 2.7, and 6.2 for Ivvavik, Bathurst, Sirmilik, and Torngat study areas, respectively. To the contrary, GSL trends tended to increase for dry classes, probably because of the effect of enhanced temperature increase at higher and usually drier locations [29]. The higher GSL increase rate together with lower $\mathrm{NPP}_{\text {leaf }}$ increase trend at the dry classes resulted in poor correspondence between $\mathrm{NPP}_{\text {leaf }}$ and GSL, and thus had a minimal or even negative contribution to their coupling strength.

Combining Equation (1) and that in Table 5 for the influence of SMRI of the class, we estimated the coupling strength for each class in the four study areas:

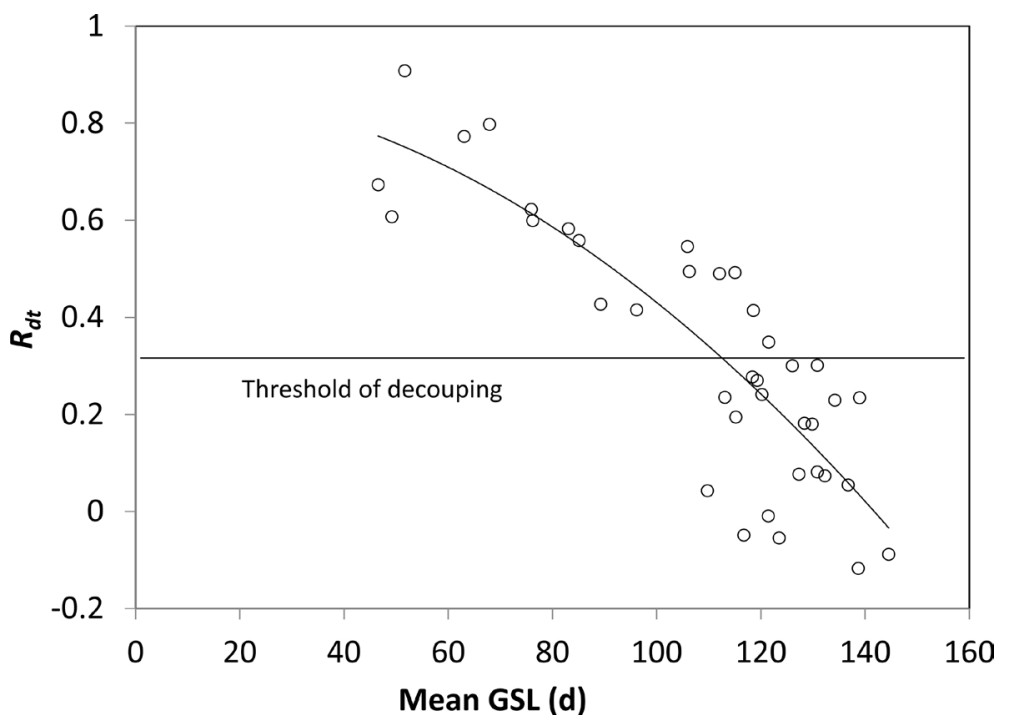

Figure 6. The relationship between the mean GSL of a tundra class and the correlation coefficient between de-trended $\mathrm{NPP}_{\text {leaf }}$ and de-trended GSL $\left(R_{d t}\right)$ over the four study areas during 1985-2013. 


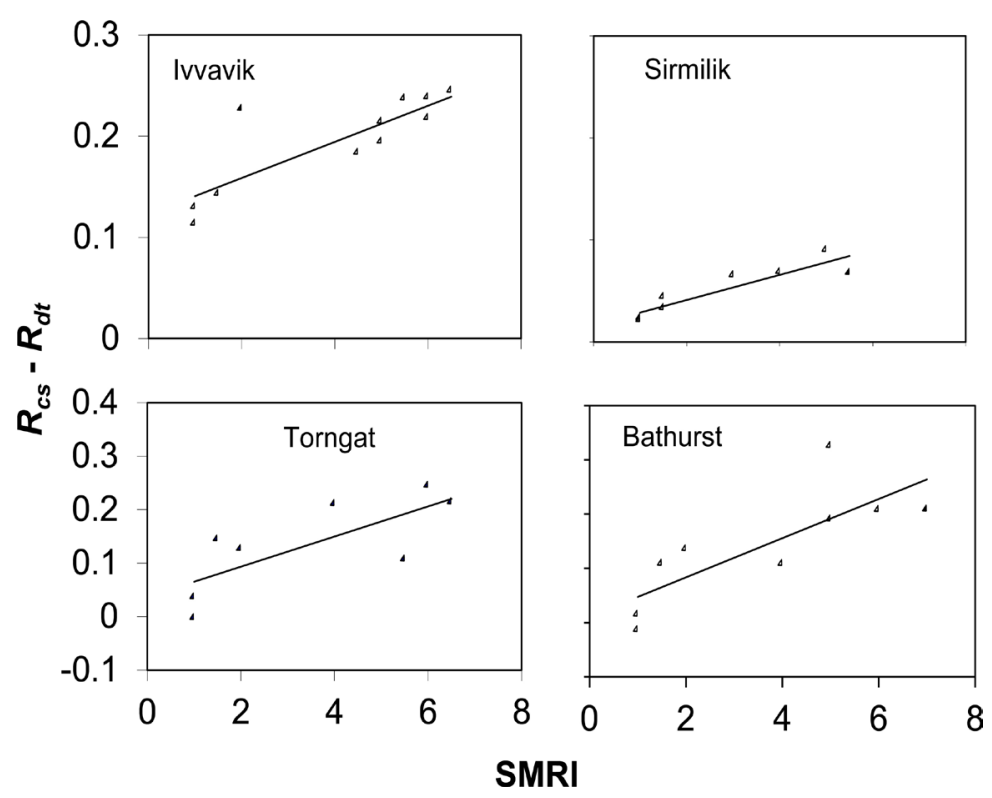

Figure 7. SMRI against the contribution of agreement between long-term trends of NPP leaf $_{\text {and }}$ GSL to the coupling strength (i.e., $R_{c s}-R_{d t}$ ) for each of the four study areas. Table 5 lists statistics for the relationships.

Table 5. Statistics for the linear relationships between the SMRI and (1) the contribution of the agreement between long-term trends of $\mathrm{NPP}_{\text {leaf }}$ and GSL to their coupling strength, as calculated by $R_{c s}-R_{d t}$; (2) the GSL trend; or (3) the NPP leaf trend for each study area during 1985-2013.

\begin{tabular}{ccccccccccc}
\hline \multirow{2}{*}{ Study area } & \multicolumn{3}{c}{ Contribution to coupling strength } & \multicolumn{3}{c}{ GSL trend } & \multicolumn{2}{c}{$\mathrm{NPP}_{\text {leaf }}$ trend } \\
\cline { 2 - 9 } & Intercept & Slope & $R^{2}$ & $p$-value & $R^{2}$ & $p$-value & $R^{2}$ & $p$-value & $n$ \\
\hline Ivvavik & 0.1229 & 0.0179 & 0.69 & 0.002 & 0.16 & 0.286 & 0.64 & 0.003 & 11 \\
Bathurst & 0.0111 & 0.0361 & 0.62 & 0.011 & 0.07 & 0.509 & 0.89 & 0.0001 & 9 \\
Sirmilik & 0.0165 & 0.0123 & 0.83 & 0.002 & 0.91 & 0.0003 & 0.73 & 0.007 & 8 \\
Torngat & 0.0371 & 0.0282 & 0.57 & 0.031 & 0.17 & 0.315 & 0.69 & 0.010 & 8 \\
\hline
\end{tabular}

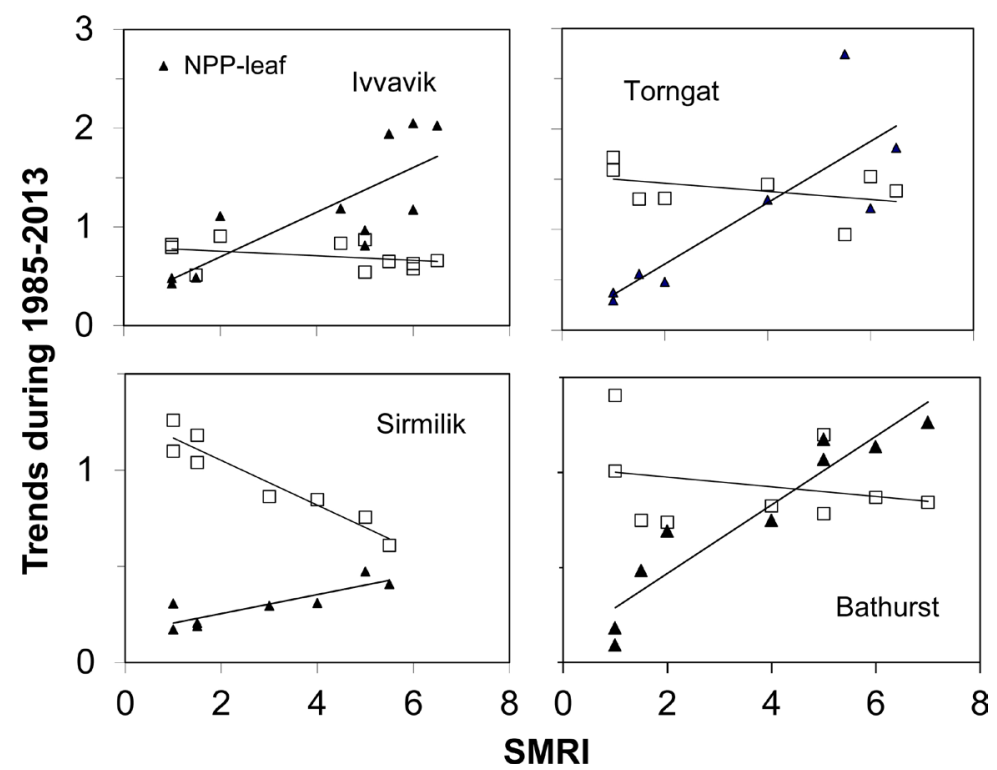

Figure 8. The relationship between SMRI and trends of NPP leaf and GSL during 1985-2013 for each of the four study areas. Table 5 lists statistics for the relationships. 


$$
R_{c s}=\left\{\begin{array}{l}
0.8817-0.000415 \overline{G S L}-0.000041(\overline{G S L})^{2}+0.1229+0.0179 \text { SMRI for Ivvavik } \\
0.8817-0.000415 \overline{G S L}-0.000041(\overline{G S L})^{2}+0.0111+0.0361 \text { SMRI for Bathurst } \\
0.8817-0.000415 \overline{G S L}-0.000041(\overline{G S L})^{2}+0.0165+0.0123 \text { SMRI for Sirmilik } \\
0.8817-0.000415 \overline{G S L}-0.000041(\overline{G S L})^{2}+0.0371+0.0282 \text { SMRI for Torngat }
\end{array}\right.
$$

with $R^{2}=0.7, p<0.01$, and $n=36$. Together, the $\overline{G S L}$ and SMRI can explain $70 \%$ of the variation in the coupling strength among all tundra classes in the four Canadian Arctic study areas (Figure 9). According to Equation (2), the relationship between NPP leaf and GSL became decoupled when $\overline{G S L}$ was $>136 \mathrm{~d}$ for tundra classes of SMRI $=6.5$, but only when $\overline{G S L}$ was $>118 \mathrm{~d}$ for tundra classes of SMRI $=1$ in the Bathurst caribou summr range and calving ground. In comparison for the Sirmilik NP, the relationship between NPP leaf and GSL became decoupled when $\overline{G S L}$ was $>123 \mathrm{~d}$ (or $116 \mathrm{~d}$ ) for tundra classes of SMRI = 6.5 (or 1). Similar results were also found for the Ivvavik NP and Torngat Mountains NP. These results thus predict that under a warming climate the decoupling could occur when the $\overline{G S L}$ would have increased to $>116 \mathrm{~d}$ for dry tundra classes and $>123 \mathrm{~d}$ for moist tundra classes in the northern Arctic. In the southern Arctic, the decoupling could occur when the $\overline{G S L}$ would have increased to $>118 \mathrm{~d}$ for dry tundra classes and $>136 \mathrm{~d}$ for moist tundra classes.

\section{Conclusions}

We estimated $\mathrm{NPP}_{\text {leaf }}$ and GSL during 1985-2013 for all tundra classes in two northern Canadian Arctic study areas and two Canadian southern Arctic study areas, using long-term remote sensing data and field vegetation measurements.

Our results showed that $44 \%$ - $64 \%$ of tundra classes in the two southern Arctic study areas had a decoupled $\mathrm{NPP}_{\text {leaf }}$ and GSL relationship during 1985-2013. The decoupling occurred for both shrub classes and non-shrub tundra classes. In the two northern Arctic and Arctic Cordillera study areas, we didn't find decoupling for all tundra classes.

The strength of coupling increased significantly with the reduction of mean GSL of a tundra class, probably because a very short growing season giving less chance for other factors (e.g. soil moisture limitation) to become influential. The mean GSL of a tundra class thus might be a good indicator of the chance that these factors

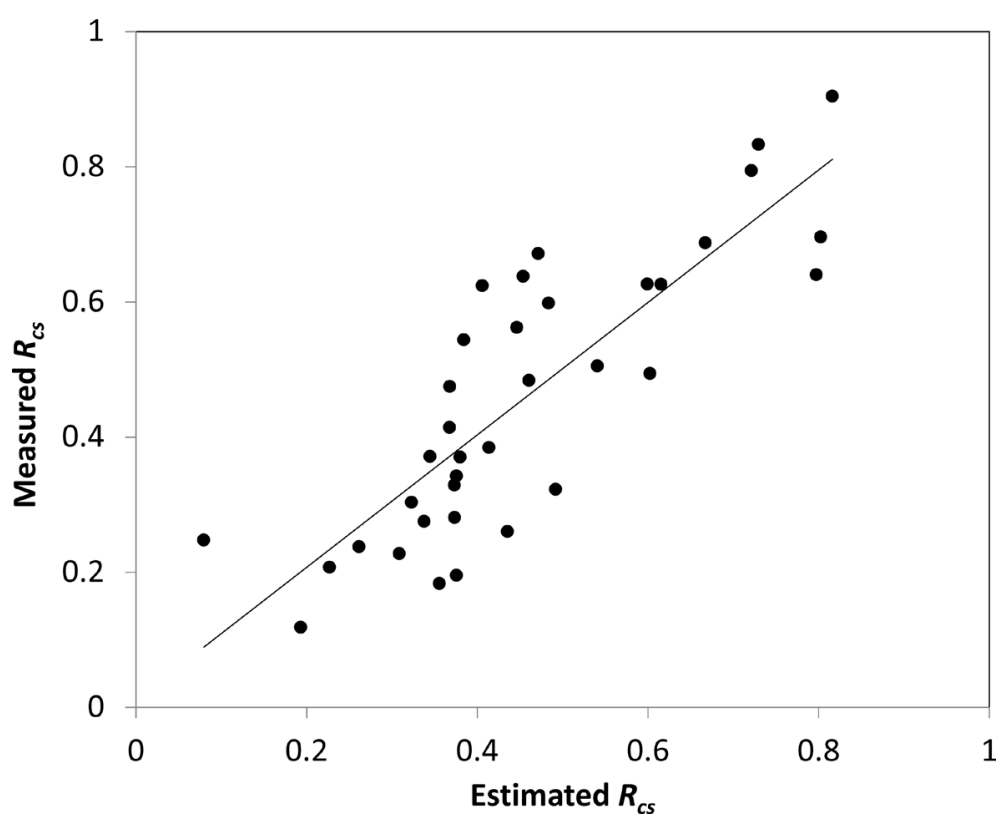

Figure 9. Comparison of coupling strength $R_{c S}$ between $\mathrm{NPP}_{\text {leaf }}$ and GSL estimated using the long-term mean GSL and SMRI against that measured directly from NPP leaf and GSL for each class during in the four study areas. 
will become influential. However, a further test of this hypothesis is needed, and collection of these datasets, along with $\mathrm{NPP}_{\text {leaf }}$ and GSL is thus of great importance.

The concurred increasing trends of $\mathrm{NPP}_{\text {leaf }}$ and GSL enhanced the coupling strength for most tundra classes. The enhancement, however, decreased significantly for drier classes, for which the long-term trend of $\mathrm{NPP}_{\text {leaf }}$ was often insignificant due to soil moisture limitation, whereas GSL increased at a similar or even higher rate than wetter classes.

Together, the mean GSL and SMRI of a tundra class can explain 70\% of the variation in the coupling strength among all tundra classes in the four Canadian Arctic study areas during 1985-2013. This result suggests that the decoupling between plant productivity and GSL would be more likely to occur under a warming climate if the tundra class had a mean GSL > 116 (or 123) days with a dry (moist) soil moisture regime.

\section{Acknowledgements}

The study was funded by the Canadian Space Agency’s Government Related Initiatives Program (GRIP), and the NWT Cumulative Impact Monitoring Program (CIMP). We thank the contribution of many northerners to the field measurements, including Alexander Gordon, Jayneta Pascal, and Kayla Arey from Aklavik, NWT; Simeonie and Jonas Johncena of Pond Inlet, Nunavut; Roy Judas and Brain Kodzin from Wekweeti. We appreciate the constructive comments by anonymous reviewers.

\section{References}

[1] Krebs, C.J., Danell, K., Angerbjörn, A., Agrell, J., Berteaux, D., Brathen, K.A., Danell, Ö., Erlinge, S., Fedorov, V., Fredga, K., Hjältén, J., Högstedt, G., Jónsdóttir, I.S., Kenney, A.J., Kjellén, N., Nordin, T., Roininen, H., Svensson, M., Tannerfeldt, M. and Wiklund, C. (2003) Terrestrial Trophic Dynamics in the Canadian Arctic. Canadian Journal of Zoology, 81, 827-843. http://dx.doi.org/10.1139/z03-061

[2] Chen, W., White, L., Adamczewski, J.Z., Croft, B., Garner, K., Pellissey, J.S., Clark, K., Olthof, I., Latifovic, R. and Finstad, G.L. (2014) Assessing the Impacts of Summer Range on Bathurst Caribou's Productivity and Abundance since 1985. Natural Resources, 5, 130-145. http://dx.doi.org/10.4236/nr.2014.54014

[3] Loranty, M.M., Berner, L.T., Goetz, S.J., Jin, Y. and Randerson, J.T. (2013) Vegetation Controls on Northern High Latitude Snow-Albedo Feedback: Observations and CMIP5 Model Predictions. Global Change Biology, 20, 594-606. http://dx.doi.org/10.1111/gcb.12391

[4] McBean, G.A., Alekseev, G., Chen, D., Forland, E., Fyfe, J., Groisman, P.Y., King, R., Melling, H., Vose, R. and Whitfield, P.H. (2005) Arctic Climate: Past and Present. In: Humfrey, M., Ed., Arctic Climate Impact Assessment, Cambridge University Press, Cambridge, 21-60.

[5] IPCC (2013) The Physical Science Basis. Cambridge University Press, Cambridge.

[6] Uston, M.A.H. and Olverton, S.W. (2009) The Global Distribution of Net Primary Production: Resolving the Paradox. Ecological Monographs, 79, 343-377. http://dx.doi.org/10.1890/08-0588.1

[7] Henry, G.H.R., Harper, K.A., Chen, W., Deslippe, J.R., Grant, R.F., Lafleur, P.M., Lévesque, E., Siciliano, S.D. and Simard, S.W. (2012) Effects of Observed and Experimental Climate Change on Terrestrial Ecosystems in Northern Canada: Results from the Canadian IPY Program. Climatic Change, 115, 207-234. http://dx.doi.org/10.1007/s10584-012-0587-1

[8] Pearson, R.G., Phillips, S.J., Loranty, M.M., Beck, P.S.A., Damoulas, T., Knight, S.J. and Goetz, S.J. (2013) Shifts in Arctic Vegetation and Associated Feedbacks under Climate Change. Nature Climate Change, 3, 673-677. http://dx.doi.org/10.1038/nclimate1858

[9] Wullschleger, S., Alsos, I.G., Eidesen, P.B., Broekman, R., Loonen, M.J.J.E. and Rozema, J. (2012) No Divergence in Cassiope Tetragonal: Persistence of Growth Response along a Latitudinal Temperature Gradient and under Multi-Year Experimental Warming. Annals of Botany, 110, 653-665. http://dx.doi.org/10.1093/aob/mcs123

[10] Myers-Smith, I.H., Elmendorf, S.C., Beck, P.S.A., Wilmking, M., Hallinger, M., Blok, D., Tape, K.D., Rayback, S.A., Macias-Fauria, M., Forbes, B.C., Speed, J.D.M., Boulanger-Lapointe, N., Rixen, C., Lévesque, E., Martin Schmidt, N., Baittinger, C., Trant, A.J., Hermanutz, L., Sieqwart Collier, L., Dawes, M.A., Lantz, T.C., Weijers, S., Halfdan Jørgensen, R., Buchwal, A., Buras, A., Naito, A.T., Ravolainen, V., Schaepman-Strub, G., Wheeler, J.A., Wipf, S., Guay, K.C., Hik, D.S. and Vellend, M. (2015) Climate Sensitivity of Shrub Growth across the Tundra Biome. Nature Climate Change. http://dx.doi.org/10.1038/nclimate2697

[11] Wiken, E.B. (1986) Terrestrial Ecozones of Canada, Ecological Land Classification Series No. 19, Environment Canada, Hull, 26 + map.

[12] Latifovic, R., Pouliot, D. and Dillabaugh, C. (2012) Identification and Correction of Systematic Error in NOAA 
AVHRR Long-Term Satellite Data Record. Remote Sensing of Environment, 127, 84-97. http://dx.doi.org/10.1016/j.rse.2012.08.032

[13] Chen, W., Zorn, P., Chen, Z., Latifovic, R., Zhang, Y., Li, J., Quirouette, J., Olthof, I., Fraser, R., Mclennan, D., Poitevin, J., Stewart, H.M. and Sharma, R. (2013) Propagation of Errors Associated with Scaling Foliage Biomass from Field Measurements to Remote Sensing Data over a Canada's Northern National Park. Remote Sensing of Environment, 130, 205-218. http://dx.doi.org/10.1016/j.rse.2012.11.012

[14] Fraser, R.H., McLennan, D., Ponomarenko, S. and Olthof, I. (2012) Image-Based Predictive Ecosystem Mapping in Canadian Arctic Parks. International Journal of Applied Earth Observation and Geoinformation, 14, 129-138. http://dx.doi.org/10.1016/j.jag.2011.08.013

[15] Olthof, I. and Fraser, R.H. (2007) Mapping Northern Land Cover Fractions Using Landsat ETM+. Remote Sensing of Environment, 107, 496-509. http://dx.doi.org/10.1016/j.rse.2006.10.009

[16] Olthof, I., Latifovic, R. and Pouliot, D. (2009) Development of a Circa 2000 Land Cover Map of Northern Canada at 30 m Resolution from Landsat. Canadian Journal of Remote Sensing, 35, 152-165. http://dx.doi.org/10.5589/m09-007

[17] MacKenzie, W., MacHutchon, G. and Jones, D. (1996) Habitat Classification for the Firth River Valley, Ivvavik National Park, Yukon. Western Arctic District, Parks Canada, Inuvik, NWT, Canada.

[18] Chen, W., Li, J., Zhang, Y., Zhou, F., Koehler, K., Leblanc, S., Fraser, R., Olthof, I., Zhang, Y.S. and Wang, J. (2009) Relating Biomass and Leaf Area Index to Non-Destructive Measurements for Monitoring Changes in Arctic Vegetation. Arctic, 62, 281-294. http://dx.doi.org/10.14430/arctic148

[19] Chen, Z., Chen, W., Leblanc, S.G. and Henry, G. (2010) Digital Photograph Analysis for Measuring Percent Plant Cover in the Arctic. Arctic, 63, 315-326. http://dx.doi.org/10.14430/arctic1495

[20] Bliss, L.C., Svoboda, J. and Bliss, D.I. (1984) Polar Deserts, Their Plant Cover and Plant Production in the Canadian High Arctic. Ecography, 7, 305-324. http://dx.doi.org/10.1111/j.1600-0587.1984.tb01136.x

[21] Iversen, C.M., Sloan, V.L., Sullivan, P.F., Euskirchen, E.S., McGuire, D.A., Norby, R.J., Walker, A.P., Warren, J.M. and Wullschleger, S.D. (2015) The Unseen Iceberg: Plant Roots in Arctic Tundra. New Phytologist, 205, 34-58. http://dx.doi.org/10.1111/nph.13003

[22] Chen, W., Chen, W.R., Li, J., Zhang, Y., Fraser, R., Olthof, I., Leblanc, S. and Chen, Z. (2012) Mapping Aboveground and Foliage Biomass over the Porcupine Caribou Habitat in Northern Yukon and Alaska Using Landsat and JERS-1/ SAR Data. In: Fatoyinbo, T., Ed., Remote Sensing of Biomass: Principles and Applications, InTECH, 231-252. http://dx.doi.org/10.5772/19219

[23] Chen, W., Foy, N., Olthof, I., Latifovic, R., Zhang, Y., Li, J., Fraser, R., Chen, Z., McLennan, D., Poitevin, J., Zorn, P., Quirouette, J. and Stewart, H.M. (2013) Evaluating and Reducing Errors in Seasonal Profiles of AVHRR Vegetation Indices over a Canadian Northern National Park Using Cloudiness Index. International Journal of Remote Sensing, 34, 4320-4343. http://dx.doi.org/10.1080/01431161.2013.775536

[24] Vermote, E.F., Tanré, D., Deuzé, J.L., Herman, M. and Morcrette, J.J. (1997) Second Simulation of the Satellite Signal in the Solar Spectrum: An Overview. IEEE Transactions on Geoscience and Remote Sensing, 35, 675-686. http://dx.doi.org/10.1109/36.581987

[25] Roy, D.P., Ju, J., Lewis, P., Schaaf, C., Gao, F., Hansen, M. and Lindquist, E. (2008) Multi-Temporal MODIS-Landsat Data Fusion for Relative Radiometric Normalization, Gap Filling, and Prediction of Landsat Data. Remote Sensing of Environment, 112, 3112-3130. http://dx.doi.org/10.1016/j.rse.2008.03.009

[26] Chen, W., Foy, N., Olthof, I., Zhang, Y., Fraser, R., Latifovic, R., Poitevin, J., Zorn, P. and McLennan, D. (2014) A Biophysically-Based and Objective Satellite Seasonality Observation Method for Applications over the Arctic. International Journal of Remote Sensing, 35, 6742-6763. http://dx.doi.org/10.1080/01431161.2014.963897

[27] Bliss, L.C. and Matveyeva, N.V. (1992) Circumpolar Arctic Vegetation. In: Chapin III, F.S., et al., Eds., Arctic Ecosystems in a Changing Climate: An Ecophysiological Perspective, Academic Press, San Diego, 59-89. http://dx.doi.org/10.1016/B978-0-12-168250-7.50010-9

[28] Edlund, S.A. and Alt, B.T. (1989) Regional Congruence of Vegetation and Summer Climate Patterns in the Queen Elizabeth Islands, Northwest Territories, Canada. Arctic, 42, 3-23. http://dx.doi.org/10.14430/arctic1635

[29] Beniston, M. and Rebetez, M. (1996) Regional Behavior of Minimum Temperatures in Switzerland for the Period 1979-1993. Theoretical and Applied Climatology, 53, 231-243. http://dx.doi.org/10.1007/BF00871739 


\section{Submit or recommend next manuscript to SCIRP and we will provide best service for you:}

Accepting pre-submission inquiries through Email, Facebook, LinkedIn, Twitter, etc.

A wide selection of journals (inclusive of 9 subjects, more than 200 journals)

Providing 24-hour high-quality service

User-friendly online submission system

Fair and swift peer-review system

Efficient typesetting and proofreading procedure

Display of the result of downloads and visits, as well as the number of cited articles

Maximum dissemination of your research work

Submit your manuscript at: http://papersubmission.scirp.org/ 